\title{
OSOBNO OČUVANJE KVALITETE ŽIVOTA, ZDRAVLJA I RADNE SPOSOBNOSTI MEDICINSKIH SESTARA
}

UDK 614.253.5:331.45

PRIMLJENO: 4.7.2018.

PRIHVAĆENO: 16.4 .2019

Ovo djelo je dano na korištenje pod Creative Commons Attribution 4.0 International License

SAŽETAK: Cilj rada je ispitati koji su najizrazitiji stresori u svakodnevnom radu medicinskih sestara/tehničara, kako djeluju na njihovo zdravlje, radnu sposobnost i kvalitetu života. Utvrđeno je postoji li razlika u rezultatima ispitivanja između zaposlenika dviju bolnica s obzirom na različitu problematiku kojom se bave. Na temelju rezultata predložene su mjere poboljšanja suočavanja sa stresom i mjere koje će pridonijeti očuvanju kvalitete života, osobnog zdravlja i radne sposobnosti. $\cup$ istraživanje je bilo uključeno 93 medicinskih sestara/tehničara zaposlenih u Specijalnoj bolnici $(S B) ;(N=38)$ i na Klinici (K); ( $N=55)$. Dragovoljno i anonimno ispitivanje provedeno je Upitnikom za procjenu utjecaja rada na zdravlje i radnu sposobnost. Podaci su uneseni u bazu podataka (Microsoft Excel for Windows), te je provedena deskriptivna statistička obrada. Razlike u kategorijskim varijablama analizirane su hi-kvadrat testom. P vrijednosti $<0,05$ smatrane su značajnima. U analizi je korištena STATISTICA verzija 10.0 (www.statsoft.com) i provedena je korelacija WAI s odgovorima ispitanika iz Upitnika, pri čemu je korišten Spearmanov koeficijent korelacije. Istraživanje je odobrilo Etičko povjerenstvo Medicinskog fakulteta Sveučilišta u Zagrebu. Između ispitivanih bolnica nema razlika u ispitivanoj skupini čimbenika koji se odnose na izazov, napredovanja i uključenost u rad organizacije $(p>0,05)$; natpolovična većina ih je nezadovoljna (52\%, odnosno $63 \%$ ). Svaki drugi ispitanik želio bi ponekad prekinuti sa svojim poslom (55\%, odnosno $58 \%$ ), petina ispitanika posao smatra obvezom i sve više odbojnim, te 62 \% nema mogućnost napredovanja. Najbolje ocijenjen segment je suradnja s kolegama. U području kvalitete života i uravnoteženosti zamijećen je veliki broj djelomično zadovoljnih i nezadovoljnih trenutnom kvalitetom života (48 \%). Niže vrijednosti WAl imaju snažnu povezanost s onima koji su nezadovoljni situacijom na poslu, kvalitetom života, lošijim svladavanjem zahtjeva na poslu, koji se osjećaju nezdravo i koji su izloženi većim zdravstvenim opterećenjima. lako se radi o relativno malom uzorku ispitanika ( $\mathrm{N}=38$, odnosno $\mathrm{N}=55)$, dobivene rezultate treba promatrati kao pokazatelje izvora organizacijskih čimbenika stresa i kao takvih uporišta na kojima se mogu planirati interventne mjere. Predložene su mjere poboljšanja u suočavanju sa stresom, te mjere koje će pridonijeti očuvanju kvalitete života i radne sposobnosti. Interventne mjere trebalo bi temeljiti na dragocjenom čimbeniku izvrsne suradnje s kolegama na poslu koju navode ispitanici.

Ključne riječi: medicinska sestra/tehničar, osobno zdravlje, kvaliteta života, radna sposobnost

\section{UVOD}

Još prije deset godina Svjetska zdravstvena organizacija proglasila je stres na radnom mjestu svjetskom epidemijom. Europski parlament pri-

*Karmela Hrastinski, mag. med. techn., (karmelahr1@gmail.com), SB za ortopediju i traumatologiju Akromion, Ljudevita Gaja 2, 49217 Krapinske Toplice. hvatio je rezoluciju u kojoj ističe potrebu usklađenosti između značajki posla i sposobnosti te potreba zaposlenika, kao i potrebu prevencije nesklada između zahtjeva posla i mogućnosti zaposlenika (engl. Resolution A4-0050/99). Naime, problem očuvanja zdravlja radnika, u svezi s opasnostima (mehaničkim, toplinskim i električnim) te štetnostima (fizikalnim, kemijskim i biološkim), 
u većini slučajeva se uspješno rješava tehničkim i tehnološkim unapređenjima na radnom mjestu, dok područje psihičkog napora, odnosno stresa, zahtijeva objektivizaciju (Šarić, Žuškin, 2002.).

Prema Europskom procjenjivanju uvjeta rada (European Working Conditions Surveys - EWCS); (2004.-2009.), koji se provodi u zemljama Europske unije i čiji se rezultati objavljuju od 2002. godine, obuhvaćeni su radno vrijeme, organizacija posla, plaće, zdravstveni rizici u vezi s radnim mjestom i njihove posljedice na zdravlje, te mogućnost usavršavanja radnika. Vidljivo je da problem procjene stresa proizašlog iz uvjeta i načina rada ostaje otvoren.

Razumijevanje radnog stresa i njegova utjecaja na zdravlje radnika važni su za cijelu radnu organizaciju zbog pravodobnog otklanjanja neželjenih posljedica. Stoga se za potrebe procjene uvjeta i načina rada koji mogu imati za posljedicu pojavu stresa u zdravstvenih djelatnika u bolnicama, odnosno prevencije posljedica stresa u organiziranju uvjeta i načina rada izradio odgovarajući mjerni instrument za procjenu opasnosti, štetnosti i napora na radnom mjestu zdravstvenih djelatnika u bolnicama, što je između ostalog i zakonska obveza u djelatnosti zdravstva (Milošević, 2010.). Upravljanje stresom jedna je od temeljnih vještina zdravog življenja, stoga sami trebamo odlučiti kako će životni zahtjevi, okolnosti i događaji djelovati na nas i kakve će biti naše reakcije.

\section{Stres}

Stres je u suvremenom svijetu prepoznat kao važan čimbenik koji utječe na zdravlje. Reakcija pojedinca na stres rezultat je preklapanja individualne osjetljivosti, vanjskih okolnosti i stresora. Individualnu osjetljivost određuju osobnost, dob i stil života. Vanjske okolnosti uključuju opći i radni okoliš, obitelj, prijatelje te uvjete i način rada. Bolesti koje mogu nastati pod utjecajem prevelikog stresa ovise o svim navedenim čimbenicima (McCunney, 1994.).

Reakcija na stres rezultat je zajedničkog djelovanja značajki, snage, duljine djelovanja stresora, zatim značajki pojedinca kao što su dob, spol, osobnost, način života, te vanjskih okolnosti u koje pripadaju okoliš, radno okružje, obitelj, prijatelji.
Reakcije na stres mogu biti:

1. Psihološke reakcije: porast tjeskobe, problemi koncentracije, negativne emocije, gubitak pažnje, depresija, umor, sindrom izgaranja ili porast samoubojstava;

2. Ponašajne reakcije su najčešće povlačenje i izolacija na poslu ili kod kuće, porast nesreća, povećanje pušenja, pijenja alkohola ili kave, razdražljivost, agresivnost, seksualne disfunkcije, niski moral te porast nasilja na poslu i/ili kod kuće;

3. Fiziološke reakcije uključuju porast razine kortizola, veće vrijednosti kolesterola, porast krvnog tlaka, palpitacije, bolove $\mathrm{u}$ prsima, nesanicu, pojavu nekih vrsta karcinoma, probavne smetnje, glavobolju, koštano-mišićne tegobe te pad funkcije imunološkog sustava (Pavičević et al., 2002.).

Stresori su događaji i situacije koje izazivaju stanje stresa. Može ih se podijeliti u kataklizmičke stresore koji djeluju na cjelokupnu populaciju, npr. rat, nuklearna nesreća, potres, zatim osobne stresore koji su također jakog intenziteta, no pogađaju pojedinca, npr. zbog smrti voljene osobe, saznanja o vlastitoj teškoj bolesti, itd., te svakodnevne stresore - dugotrajne ponavljajuće događaje koji čine dio svakodnevnog života, a nisu jakog intenziteta (Pavičević et al., 2002.).

\section{Stres na radu}

Karasek (1981.) je osamdesetih godina prošlog stoljeća razvio model stresa na radu koji je zorno predočio kao dvije dimenzije u kojima razina stresa raste kako se povećavaju zahtjevi radnoga mjesta, a smanjuje razina odlučivanja pri čemu stres na radu nije rezultat samo jednog čimbenika nego je zbroj povećanih zahtjeva i niske razine odlučivanja.

Većina uzroka stresa pri radu tiče se načina na koji je rad planiran i načina na koji se upravlja organizacijama. Zbog toga što ti aspekti rada mogu prouzročiti štetu, naziva ih se "opasnosti povezane sa stresom" (Leka et al., 2003.).

Literatura o stresu (Milošević, 2010.) općenito priznaje devet kategorija opasnosti povezanih sa stresom: značajke posla, radno opterećenje i brzina rada, radni sati, sudjelovanje i kontrola, orga- 
nizacijska kultura, razvoj karijere, status i plaća, uloga u organizaciji, međuljudski odnosi, veza posao - dom.

Izvori profesionalnog stresa mogu biti:

- Unutrašnji - oni koji prvenstveno ovise o pojedincu, osobinama ličnosti, prethodnom iskustvu, stilu rada, sustavu vrijednosti, slici koju imaju o sebi. Očituju se kao nerealna očekivanja od posla i od sebe samog, koja nadilaze radni realitet; potreba za stalnom i potpunom kontrolom situacije, pretjerana vezanost za posao i osjećaj pojedinca da snosi svu odgovornost, identifikacija s poslom u tolikoj mjeri da on postaje glavni ili jedini sadržaj i smisao života, jedino područje potvrđivanja, neprepuštanje dijelova poslova drugima; pretjerana upornost, rigidnost i tvrdoglavost $\mathrm{u}$ postizanju cilja pod bilo koju cijenu.

- Vanjski - povezani s radnim uvjetima, organizacijom rada i oni koji izviru iz odnosa s drugim ljudima (Milošević, 2010.).

\section{Stres kod zdravstvenih djelatnika}

Profesija medicinske sestre/tehničara najbrojnija je unutar zdravstvenog sustava. Rad medicinske sestre/tehničara podrazumijeva brigu za pacijenta tijekom dvadeset i četiri sata, te je stoga najviše izložena negativnim utjecajima koji narušavaju i ugrožavaju njihovo psihičko i fizičko zdravlje. Na svojim radnim mjestima izloženi su čitavom nizu mehaničkih opasnosti, kemijskim, fizikalnim i biološkim čimbenicima, ergonomskim uvjetima te psihološkim zahtjevima proizašlih ne samo od izravnog dodira s oboljelima, nego i iz niza nepovoljnih utjecaja uvjeta i načina rada, te stoga utječe na njihovo zdravlje (Paravlić, 2006.).

Produljeno radno vrijeme, smjenski i noćni rad, odgovornost pri donošenju odluka, kontakt s oboljelima i njihovim obiteljima i emocionalno iscrpljivanje (engl. burn-out) u zdravstvenih djelatnika pridonose povećanom morbiditetu od psihičkih smetnji i psihosomatskih bolesti (Zeng, 2009., Kinzl et al., 2006., Robinson et al., 2003., Visser et al., 2003.).

Među uzrocima emocionalnog iscrpljivanja su također i organizacija zadataka, zatrpanost po- slom, premalo vremena za odmor, rutinski i mehanički zadaci koji iziskuju vrlo malo kreativnosti i daju malo mogućnosti za kontrolu vlastitog rada, zatim stil menadžmenta; nedostatak sudjelovanja u donošenju odluka, slaba komunikacija unutar tvrtke, međuljudski odnosi; nedostatak bliskosti među radnicima, uzajamne pomoći i podrške, nesigurnost radnog mjesta; stalan strah od otpuštanja, nemogućnost napredovanja u osobnom, stručnom ili karijernom smislu, česte promjene u organizaciji posla, radna okolina; prostori u kojima se ljudi ne osjećaju ugodno, bilo zbog njihovog izgleda, veličine, pretrpanosti, buke, zagađenja ili ergonomskih problema (Zeng, 2009., Kinzl et al., 2006., Robinson et al., 2003., Visser et al., 2003.).

Kod pogođenih pojedinaca javljaju se:

- promjene ponašanja u obliku pada koncentracije, smanjenja samopoštovanja, apatije, nepopustljivosti i krutosti u odnosima, dezorijentacije, perfekcionizma, zabrinutosti za zdravlje, nestrpljivosti, pretjerane opreznosti, povlačenja u sebe i izolacije od drugih, pretjerane zabrinutosti za obitelj, nesnošljivosti, sklonosti konfliktima, preosjetljivosti itd.,

- razni subjektivni simptomi kao što su nesanica, noćne more, smanjenje ili pojačanje apetita, pad seksualnosti, osjećaj iracionalnog straha, osjećaj krivnje, umor, stalno loše raspoloženje, opća slabost itd.,

- psihičke promjene u obliku pojave opsesija svrsishodnosti života, osjećaja besciljnosti i suicidalnih primisli, vjerskog fanatizma ili gubitka vjere, patološkog skepticizma itd.,

- organski poremećaji kao što su srčane artimije, napadi paroksizmalne tahikardije, pojava hipertenzije, poremećaji menstrualnog ciklusa itd.

\section{Pojmovni okviri kvalitete života}

Kvaliteta života je multidimenzionalni pojam, te je predmet interesa mnogih disciplina, kao što su medicina, javno zdravstvo, pravo, filozofija, psihologija, ekonomija i sociologija.

Kvalitetu života kao multidimenzionalni konstrukt može se raščlaniti u dvije osnovne komponente: objektivnu i subjektivnu. Mjerljivi objek- 
tivni parametri su osobni dohodak, zdravlje, edukacijski stupanj, zaposlenje, ušteda i mnogi drugi (Ventegodt, 2003.). Prema Cumminsu (Germano, 1996., Cummins, 1993.) postoji 7 domena relevantnih za subjektivnu komponentu kvalitete života: materijalno blagostanje, zdravlje, produktivnost, intimnost, sigurnost, mjesto u društvu, te emocionalno blagostanje.

Cummins je također evaluirao korelaciju između objektivnih i subjektivnih indikatora kvalitete života na temelju rezultata 10 istraživanja i zaključio da je ta korelacija niska i nelinearnog karaktera (Blore, 2008., Cummins, 2000.).

Najčešće korišteni termin je kvaliteta života, a odnosi se zapravo na subjektivno zadovoljstvo životom u cjelini ili njegovim pojedinim aspektima (Cummins, 2000.).

\section{CILJ ISTRAŽIVANJA}

Opći cilj istraživanja je ispitati koji su najizrazitiji stresori u svakodnevnom radu medicinskih sestara/tehničara te kako djeluju na njihovo zdravlje, radnu sposobnost i kvalitetu života.

U tu svrhu postavljeni su specifični ciljevi:

1. Ispitati čine li uvjeti i način rada te neodgovarajuća socijalna podrška najveće stresore u svakodnevnom radu medicinskih sestara/tehničara.

2. Na temelju dobivenih rezultata predložiti mjere poboljšanja suočavanja sa stresom i mjere koje će pridonijeti očuvanju kvalitete života, osobnog zdravlja i radne sposobnosti.

\section{HIPOTEZA}

H1 - Uvjeti i način rada, te neodgovarajuća socijalna podrška najveći su stresori u svakodnevnom radu medicinskih sestara/tehničara.

H2 - Stresori u svakodnevnom radu medicinskih sestara/tehničara utječu na osobno zdravlje, kvalitetu života i radnu sposobnost medicinskih sestara/tehničara.

\section{METODOLOGIJA ISTRAŽIVANJA}

\section{Ispitanici}

U istraživanje je bilo uključeno 93 medicinskih sestara/tehničara, srednje, više i visoke stručne spreme zaposlenih u SB $(\mathrm{N}=38)$ i u $\mathrm{K}(\mathrm{N}=55)$.

\section{Metode}

Prikupljanje podataka bilo je dragovoljno i anonimno, a provodilo se putem Upitnika za procjenu utjecaja rada na zdravlje i radnu sposobnost IBG - Institut für human ökologische Unternehmensführung i Škole narodnog zdravlja "Andrija Štampar". Upitnici su predani glavnom tehničaru u SB i K, te su ih zainteresirani djelatnici preuzeli i ispunjene vratili u zapečaćenu kutiju.

Dobiveni podaci uneseni su u bazu podataka i provedena je deskriptivna statistička obrada. Razlike u kategorijskim varijablama analizirane su hi-kvadrat testom. P vrijednosti $<0,05$ smatrane su značajnima. U analizi je korištena STATISTICA verzija 10.0 (www.statsoft.com). Izračunat je indeks radne sposobnosti (WAI), te je provedena korelacija s odgovorima ispitanika iz Upitnika za procjenu radne sposobnosti. Korišten je Spearmanov koeficijent korelacije, a rezultati su prikazani tablično i grafički.

Istraživanje je odobrilo Etičko povjerenstvo Medicinskog fakulteta Sveučilišta u Zagrebu, te su dobivene suglasnosti ravnatelja za provođenje istraživanja.

\section{REZULTATI}

SB zapošljava 203 medicinske sestre/tehničara, od toga 148 je srednje stručne spreme, 49 više stručne spreme (prvostupnika sestrinstva) i 6 visoke stručne spreme. Podijeljeno je 75 upitnika, a odazvalo se 38 medicinskih sestara/tehničara (odaziv 51 \%).

Klinika zapošljava 111 medicinskih sestara/tehničara, od toga je 84 srednje stručne spreme, 24 više stručne spreme (prvostupnika sestrinstva) i 3 visoke stručne spreme (2 magistra sestrinstva i 1 diplomirana medicinska sestra/tehničar). Podijeljeno je 75 upitnika, a odazvalo se 55 medicinskih sestara/tehničara (odaziv $73 \%$ ). 


\section{Sociodemografski pokazatelji ispitanika}

Ispitanici su u obje bolnice više od 80 \% žene (Tablica 1). Statistički je značajna razlika u dobi i duljini radnog staža ispitanika.
Medijan dobi ispitanika SB iznosi 49 (39-55), a $K 41$ (35-48), $p=0,005$, a medijan duljine radnog staža u SB iznosi 29 (21- 35), a u K 22 (1526), $p=0,005$ (Tablica 2).

Tablica 1. Sociodemografski pokazatelji ispitanika

Table 1. Sociodemographic indicators of the participants

\begin{tabular}{|c|c|c|c|c|}
\hline \multirow{2}{*}{ Podaci za socijalnu statistiku } & \multicolumn{3}{|c|}{ Broj (\%) ispitanika } & \multirow{2}{*}{$\mathbf{P *}$} \\
\hline & SB & $\mathbf{K}$ & Ukupno & \\
\hline \multicolumn{5}{|l|}{ Spol } \\
\hline 1. Žensko & $34(89)$ & $45(82)$ & $79(85)$ & \multirow{2}{*}{0,39} \\
\hline 2. Muško & $4(11)$ & $10(18)$ & $14(15)$ & \\
\hline \multicolumn{5}{|l|}{ Bračno stanje? } \\
\hline 1. Neoženjen/neudana & $4(11)$ & $10(18)$ & $14(15)$ & \multirow{5}{*}{0,06} \\
\hline 2. Oženjen/udana & $31(82)$ & $36(65)$ & $67(72)$ & \\
\hline 3. Izvanbračna zajednica & 0 & $7(13)$ & $7(8)$ & \\
\hline 4. Rastavljen/a & $3(7)$ & $1(2)$ & $4(4)$ & \\
\hline Bez odgovora & 0 & $1(2)$ & $1(1)$ & \\
\hline \multicolumn{5}{|l|}{ Trenutno živite: } \\
\hline 1. Sami & $2(5)$ & $4(7)$ & $6(6)$ & \multirow{5}{*}{0,93} \\
\hline 2. U obitelji/partnerstvu s djecom & $28(74)$ & $39(71)$ & $67(72)$ & \\
\hline 3. U obitelji/partnerstvu bez djece & $6(16)$ & $8(15)$ & $14(15)$ & \\
\hline 4. Sam/a s djecom & $2(5)$ & $3(5)$ & $5(5)$ & \\
\hline Bez odgovora & 0 & $1(2)$ & $1(1)$ & \\
\hline \multicolumn{5}{|c|}{ Stanujete li geografski odvojeno od Vaše obitelji/partnerstva } \\
\hline 1. $\mathrm{Ne}$ & $36(95)$ & $53(96)$ & $89(96)$ & \multirow{3}{*}{0,47} \\
\hline 2. Da, tijekom tjedna & $2(5)$ & $1(2)$ & $3(3)$ & \\
\hline 3. Da, tijekom dužeg vremena & 0 & $1(2)$ & $1(1)$ & \\
\hline
\end{tabular}

${ }^{*} \chi^{2}$ test

Tablica 2. Interkvartilni raspon dobi ispitanika i duljine radnog staža

Table 2. Interquartile range of the age and years of work

\begin{tabular}{|c|c|c|c|}
\hline \multirow{2}{*}{} & \multicolumn{2}{|c|}{ Medijan (interkvartilni raspon) } & \multirow{2}{*}{ P* } \\
\cline { 2 - 3 } & SB & K & 0,005 \\
\hline Dob ispitanika (godine) & $49(39-55)$ & $41(35-48)$ & 0,005 \\
\hline Duljina radnog staža (godine) & $29(21-35)$ & $22(15-26)$ & 0 \\
\hline
\end{tabular}

*Mann Whitney U test 
Tablica 3. Sociodemografski pokazatelji ispitanika (nastavak)

Table 3. Sociodemographic indicators of the participants (continued)

\begin{tabular}{|c|c|c|c|c|}
\hline \multirow{2}{*}{ Podaci za socijalnu statistiku } & \multicolumn{3}{|c|}{ Broj $(\%)$ ispitanika } & \multirow{2}{*}{ P* } \\
\hline & SB & K & Ukupno & \\
\hline \multicolumn{5}{|l|}{ Vaše radno vrijeme: } \\
\hline 1. Normalno puno radno vrijeme & $21(55)$ & $20(36)$ & $41(44)$ & \multirow{5}{*}{0,21} \\
\hline 2. Djelomično, nepuno radno vrijeme & $1(3)$ & $1(2)$ & $2(2)$ & \\
\hline 3. Smjenski rad s noćnim smjenama i rad vikendom & $14(37)$ & $31(56)$ & $45(48)$ & \\
\hline 5. Smjenski rad bez noćnih smjena i rada vikendom & $2(5)$ & $1(2)$ & $3(3)$ & \\
\hline 7. Radno vrijeme po potrebi & 0 & $2(3)$ & $2(2)$ & \\
\hline \multicolumn{5}{|c|}{ Kakvo je Vaše zakonsko tjedno radno vrijeme bez prekovremenih sati? } \\
\hline 1. Manje od 32 sata & $1(3)$ & $2(4)$ & $3(3)$ & \multirow{3}{*}{0,90} \\
\hline 4. $38-39.9$ sati & $2(5)$ & $2(4)$ & $4(4)$ & \\
\hline 5. 40 i više sati & $35(92)$ & $51(93)$ & $86(92)$ & \\
\hline \multicolumn{5}{|l|}{ Koliko prosječno prekovremenih sati radite tjedno? } \\
\hline 1. 1-5 sati & $20(53)$ & $35(64)$ & $55(59)$ & \multirow{4}{*}{$<0,001$} \\
\hline 2. 6-10 sati & 0 & $14(25)$ & $14(15)$ & \\
\hline 4. Više od 15 sati & 0 & $2(4)$ & $2(2)$ & \\
\hline Bez prekovremenih sati & $18(47)$ & $4(7)$ & $22(23)$ & \\
\hline \multicolumn{5}{|c|}{ Koliko vremena, u satima, putujete na posao tijekom radnog dana (na posao i natrag)? } \\
\hline 1. Do 1 sat & 0 & $33(60)$ & $33(35)$ & \multirow{4}{*}{$<0,001$} \\
\hline 2. Do 2 sata & $36(95)$ & $13(24)$ & $49(53)$ & \\
\hline 3. Do 3 sata & $2(5)$ & $7(13)$ & $9(10)$ & \\
\hline 4. Više od 3 sata & 0 & $2(3)$ & $2(2)$ & \\
\hline \multicolumn{5}{|l|}{ Koliko dugo radite u smjeni? } \\
\hline 1. Do 1 godine & $4(11)$ & $7(13)$ & $11(12)$ & \multirow{7}{*}{0,001} \\
\hline 2. 3-5 godina & $3(8)$ & $7(13)$ & $10(11)$ & \\
\hline 3. 6-10 godina & $6(16)$ & $3(5)$ & $9(10)$ & \\
\hline 4. $11-20$ godina & $7(18)$ & $7(12)$ & $14(15)$ & \\
\hline 5. 21-30 godina & $3(7)$ & $23(41)$ & $26(28)$ & \\
\hline 6. Više od 30 godina & $12(31)$ & $3(5)$ & $15(16)$ & \\
\hline Bez odgovora & $3(7)$ & $5(9)$ & $8(8)$ & \\
\hline \multicolumn{5}{|l|}{ Koliko dugo radite na ovom radnom mjestu? } \\
\hline 1. Do 1 godine & $2(5)$ & $8(15)$ & $10(11)$ & \multirow{8}{*}{0,001} \\
\hline 2. 3-5 godina & $6(16)$ & $5(9)$ & $11(12)$ & \\
\hline 3. $6-10$ godina & $4(11)$ & $5(9)$ & $9(10)$ & \\
\hline 4. 11-20 godina & $9(23)$ & $32(58)$ & $41(44)$ & \\
\hline 5. 21-30 godina & $9(23)$ & $4(7)$ & $13(14)$ & \\
\hline 6. Više od 30 godina & $7(18)$ & 0 & $7(7)$ & \\
\hline Bez odgovora & $1(2)$ & $1(2)$ & $2(2)$ & \\
\hline Ukupno & $38(100)$ & $55(100)$ & $93(100)$ & \\
\hline
\end{tabular}




\begin{tabular}{||l|c|c|c|c|}
\hline \hline Vaš najviši završeni stupanj obrazovanja: \\
\hline 1. Srednje obrazovanje & $18(47)$ & $37(67)$ & $55(59)$ & $26(28)$ \\
\hline 2. Više obrazovanje & $14(37)$ & $12(22)$ & $10(11)$ & 0,10 \\
\hline 3. Visoko obrazovanje & $6(16)$ & $4(7)$ & $2(2)$ \\
\hline 4. Magisterij & 0 & $2(3)$ & $2(2)$ \\
\hline
\end{tabular}

${ }^{*} \chi^{2}$ test

Očekivano, najveći broj ispitanika je sa srednjom stručnom spremom. Obrazovna struktura u SB sa završenim srednjim obrazovanjem je $47 \%$, s višim obrazovanjem $36 \%$, a s visokim obrazovanjem $15 \%$, dok je u $\mathrm{K}$ sa završenim srednjim obrazovanjem udio daleko viši, $67 \%$, s višim obrazovanjem manji, $21 \%$, kao i s visokim obrazovanjem, $7 \%$, ali imaju $3 \%$ s magisterijem.

U SB normalno radno vrijeme radi $55 \%$ ispitanika, $36 \%$ radi smjenski rad s noćnim smjenama i radom vikendom. Udio onih koji rade smjenski rad s noćnim smjenama i radom vikendom u $\mathrm{K}$ je veći, $56 \%$, a normalno radno vrijeme radi također $36 \%$ ispitanika (Tablica 3).

\section{Izazov, napredovanja i uključenost u rad organizacije}

U Tablici 4 prikazani su odgovori dobiveni na skupinu pitanja koja opisuje izazove, napredovanja i uključenost u rad organizacije u SB i K. Između ispitivanih bolnica u ovoj skupini nema statistički značajnih razlika ( $p>$ 0,05).

Većina je nezadovoljna sa sadašnjom situacijom na poslu i zanimanjem, $52 \%$, odnosno $63 \%$. lako svoj poslovni život doživljavaju pretežno kao svrhu i mogućnost za održanje života $44 \%$, odnosno $58 \%$, nemali udio je onih koji ga doživljavaju izazovnim, zanimljivim i smislenim, $31 \%$, odnosno $21 \%$.

Ne ohrabruje podatak da ih se natpolovična većina ne razvija usporedo s tijekom razvoja njihovih ustanova. Rijetko ili nikad ne dobivaju u tim razdobljima napredovanja, $65 \%$ odnosno $60 \%$. Nasuprot tome, značajan je udio onih koji rade izravno surađujući, zajedno $\mathrm{s}$ kolegama, $78 \%$ odnosno $74 \%$ (Tablica 4 ).

Tablica 4. Izazov, napredovanje i uključenost u rad organizacije

Table 4. Challenge, promotion and involvement in the work of the organisation

\begin{tabular}{|c|c|c|c|c|}
\hline \multirow{2}{*}{ Izazov, napredovanje i uključenost u rad organizacije } & \multicolumn{3}{|c|}{ Broj $(\%)$ ispitanika } & \multirow{2}{*}{$\mathbf{P}^{*}$} \\
\hline & SB & K & Ukupno & \\
\hline \multicolumn{5}{|c|}{ U kojoj ste mjeri zadovoljni s Vašom sadašnjom situacijom na poslu i zanimanjem? } \\
\hline 1. Vrlo zadovoljan/a & $1(3)$ & $5(9)$ & $6(6)$ & \multirow{5}{*}{0,59} \\
\hline 2. Prilično zadovoljan/a & $14(37)$ & $15(27)$ & $29(31)$ & \\
\hline 3. Djelomično zadovoljan/a & $19(50)$ & $26(47)$ & $45(48)$ & \\
\hline 4. Prilično nezadovoljan/a & $3(7)$ & $6(10)$ & $9(9)$ & \\
\hline 5. Vrlo nezadovoljan/a & $1(2)$ & $3(5)$ & $4(4)$ & \\
\hline \multicolumn{5}{|l|}{ Doživljavate li svoj poslovni život pretežno...? } \\
\hline 1. Izazovnim, zanimljivim i smislenim & $12(32)$ & $12(22)$ & $24(26)$ & \multirow{5}{*}{0,62} \\
\hline 2. Kao svrhu i mogućnost za održanje života & $17(45)$ & $32(58)$ & $49(53)$ & \\
\hline 3. Kao obavezu & $7(18)$ & $9(16)$ & $16(17)$ & \\
\hline 4. Kao prisilu & $2(5)$ & $2(3)$ & $4(4)$ & \\
\hline 5. S vremenom sve više odbojnim & $12(32)$ & $12(22)$ & $24(26)$ & \\
\hline
\end{tabular}




\begin{tabular}{||l|c|c|c|c|}
\hline \multicolumn{2}{|l|}{ Dobivate li i Vi napredovanja tijekom razvoja Vaše radne organizacije? } & $4(7)$ & $4(4)$ \\
\hline 1. U većini slučajeva da & $1(3)$ & $2(4)$ & $3(3)$ \\
\hline 2. Prilično često & $11(29)$ & $15(27)$ & $26(28)$ \\
\hline 3. Ponekad & $13(34)$ & $16(29)$ & $29(31)$ \\
\hline 4. Prilično rijetko & $12(31)$ & $17(30)$ & $29(31)$ \\
\hline 5. Nikad & $1(2)$ & $1(2)$ & $2(2)$ \\
\hline Bez odgovora & $30(79)$ & $41(75)$ & $71(76)$ \\
\hline Doživljavate li da u Vašem zanimanju prevladava & $7(18)$ & $9(16)$ & $16(17)$ \\
\hline 1. Direktna suradnja - rad zajedno s kolegama & 0 & $3(5)$ & $3(3)$ \\
\hline 2. Indirektna suradnja - rad za isti cilj, ali odvojeno od kolega & $1(2)$ & 0 & $1(1)$ \\
\hline 3. Rad 'protiv drugog' & 0 & $2(3)$ & $2(2)$ \\
\hline 4. Samostalan rad - pojedinačno & & & \\
\hline Bez odgovora & & & \\
\hline
\end{tabular}
${ }^{*} \chi^{2}$ test

\section{Kvaliteta života i uravnoteženost}

Između ispitivanih bolnica niti u ovoj skupini nema statistički značajnih razlika ( $p>0,05)$. Kvalitetu svojeg života i uravnoteženost privatnog i radnog dijela obje skupine ispitanika doživljavaju podjednako: pretežno je zadovoljno $55 \%$, odnosno $49 \%$, isto tako ih je gotovo podjednak udio djelomično zadovoljno $42 \%$, odnosno $47 \%$. Ohrabruje podatak da je svega $2 \%$, odnosno $3 \%$ nezadovoljnih.

Svaki drugi ispitanik želio bi ponekad prekinuti sa svojim poslom, $55 \%$, odnosno $58 \%$. Svoju sadašnju životnu situaciju najvećim dijelom opisuju kao „ispunjen privatni život, a profesionalni ponekad", $49 \%$, odnosno $63 \%$ (Tablica 5).

\section{Tablica 5. Kvaliteta života i uravnoteženost}

Table 5. Quality of work life balance

\begin{tabular}{|c|c|c|c|c|}
\hline \multirow{2}{*}{ Kvaliteta života i uravnoteženost } & \multicolumn{3}{|c|}{ Broj $(\%)$ ispitanika } & \multirow{2}{*}{$\mathbf{P}^{*}$} \\
\hline & SB & $\mathbf{K}$ & Ukupno & \\
\hline \multicolumn{5}{|l|}{ Koliko ste zadovoljni s trenutnom kvalitetom Vašeg života? } \\
\hline 1. Vrlo zadovoljan/a & $2(5)$ & $3(5)$ & $5(5)$ & \multirow{5}{*}{0,53} \\
\hline 2. Prilično zadovoljan/a & $19(50)$ & $24(44)$ & $43(46)$ & \\
\hline 3. Djelomično zadovoljan/a & $16(42)$ & $26(47)$ & $42(45)$ & \\
\hline 4. Prilično nezadovoljan/a & 0 & $2(3)$ & $2(2)$ & \\
\hline 5. Vrlo nezadovoljan/a & $1(2)$ & 0 & $1(1)$ & \\
\hline \multicolumn{5}{|l|}{ Želite li ponekad prekinuti s Vašim poslom? } \\
\hline 1. Ne, nikada & $12(32)$ & $9(16)$ & $21(23)$ & \multirow{4}{*}{0,14} \\
\hline 2. Ponekad mislim o tome, ali se ipak odlučim za svoj sadašnji posao & $21(55)$ & $32(58)$ & $53(57)$ & \\
\hline 3. Sve češće to želim & $5(13)$ & $10(18)$ & $15(16)$ & \\
\hline 4. Da, jako želim prekinuti posao i često odlazim na posao s odbojnošću & 0 & $4(7)$ & $4(4)$ & \\
\hline
\end{tabular}




\begin{tabular}{|c|c|c|c|c|}
\hline \multicolumn{5}{|l|}{ Koja od navedenih rečenica najbolje opisuje Vašu sadašnju životnu situaciju? } \\
\hline $\begin{array}{l}\text { 1. Sve u svemu proživljavam ispunjen privatan život i interesantan } \\
\text { profesionalan život. Osjećam da mi takav život odgovara kao cjelina. }\end{array}$ & $9(24)$ & $9(16)$ & $18(19)$ & \multirow{4}{*}{0,12} \\
\hline $\begin{array}{l}\text { 2. Proživljavam ispunjen privatan život, ali je moj profesionalan život } \\
\text { samo ponekad interesantan. Osjećam da mi privatan život odgovara, ali } \\
\text { profesionalan samo ponekad. }\end{array}$ & $19(50)$ & $38(69)$ & $57(61)$ & \\
\hline $\begin{array}{l}\text { 3. Proživljavam ispunjen i interesantan profesionalan život, ali je moj } \\
\text { privatan život samo ponekad ispunjen. Osjećam da mi profesionalan život } \\
\text { odgovara, ali privatan samo ponekad. }\end{array}$ & $4(11)$ & $1(2)$ & $5(5)$ & \\
\hline $\begin{array}{l}\text { 4. Trenutno ne osjećam dovoljno ispunjenje ni u privatnom, niti u } \\
\text { profesionalnom. Osjećam da mi u zadnje vrijeme u životu ide 'u krivom } \\
\text { smjeru'. }\end{array}$ & $6(15)$ & $5(9)$ & $11(11)$ & \\
\hline Bez odgovora & 0 & $2(3)$ & $2(2)$ & \\
\hline
\end{tabular}

${ }^{*} \chi^{2}$ test

\section{Sadašnja radna sposobnost}

Sadašnja radna sposobnost prikazana je indeksom radne sposobnosti.

Od 93 ispitanika:

- WAI 7 - 27 imaju 4 ispitanika (pokazuje lošu radnu sposobnost)

Tablica 6. Indeks radne sposobnosti

Table 6. Work capacity index

\begin{tabular}{|c|c|c|}
\hline \multirow{10}{*}{ Sadašnja radna sposobnost na skali od 1 do 10} & 1 & 0 \\
\hline & 2 & 0 \\
\hline & 3 & 1 \\
\hline & 4 & 1 \\
\hline & 5 & 6 \\
\hline & 6 & 6 \\
\hline & 7 & 21 \\
\hline & 8 & 23 \\
\hline & 9 & 19 \\
\hline & 10 & 16 \\
\hline \multirow{5}{*}{ Koliko ste trenutno uspješni u svladavanju fizičkih zahtjeva na poslu? } & Vrlo dobro & 29 \\
\hline & Prilično dobro & 45 \\
\hline & Osrednje & 18 \\
\hline & Prilično loše & 1 \\
\hline & Vrlo loše & 0 \\
\hline \multirow{5}{*}{ Koliko ste trenutno uspješni u svladavanju psihičkih zahtjeva na poslu? } & Vrlo dobro & 22 \\
\hline & Prilično dobro & 53 \\
\hline & Osrednje & 17 \\
\hline & Prilično loše & 1 \\
\hline & Vrlo loše & 0 \\
\hline
\end{tabular}

- WAI 28 - 36 ima 32 ispitanika (pokazuje dobru radnu sposobnost)

- WAI 37 - 43 ima 39 ispitanika (pokazuje vrlo dobru radnu sposobnost) $\mathrm{i}$

- WAI 44 - 49 ima 18 ispitanika (pokazuje odličnu radnu sposobnost). 


\begin{tabular}{|c|c|c|}
\hline \multirow{6}{*}{ Broj trenutnih bolesti koje vam je dijagnosticirao liječnik! } & 0 & 22 \\
\hline & 1 & 14 \\
\hline & 2 & 11 \\
\hline & 3 & 14 \\
\hline & 4 & 10 \\
\hline & 5 & 22 \\
\hline \multirow{6}{*}{$\begin{array}{l}\text { Ometa li vas u posljednje vrijeme vaša bolest ili ozljeda u izvođenju } \\
\text { vašeg posla? }\end{array}$} & 1. Sada me ne ometaju ni bolest niti ozljeda & 41 \\
\hline & $\begin{array}{l}\text { 2. Mogu izvršavati svoj posao, ali to } \\
\text { uzrokuje tegobe }\end{array}$ & 36 \\
\hline & $\begin{array}{l}\text { 3. Ponekad sam prisiljen/a raditi sporije ili } \\
\text { promijeniti metodu rada }\end{array}$ & 13 \\
\hline & $\begin{array}{l}\text { 4. Često sam prisiljen/a raditi sporije ili } \\
\text { promijeniti metodu rada }\end{array}$ & 3 \\
\hline & $\begin{array}{c}\text { 5. Zbog svoje bolesti, dosadašnji posao } \\
\text { mogu obavljati samo u ograničenom } \\
\text { vremenu }\end{array}$ & 0 \\
\hline & $\begin{array}{l}\text { 6. Po mojem mišljenju, trenutno sam } \\
\text { potpuno radno nesposoban/a }\end{array}$ & 0 \\
\hline \multirow{8}{*}{$\begin{array}{l}\text { Koliko ste cijelih dana izostali s posla zadnjih } 12 \text { mjeseci zbog } \\
\text { zdravstvenih problema (bolest, zdravstvena zaštita)? }\end{array}$} & 1. Niti jedan dan & 61 \\
\hline & 2. $1-9$ & 17 \\
\hline & 3. $10-18$ & 7 \\
\hline & 4. $19-24$ & 3 \\
\hline & 5. $25-40$ & 1 \\
\hline & 6. $41-60$ & 3 \\
\hline & 7. $61-99$ & 0 \\
\hline & 8. $100-365$ & 1 \\
\hline \multirow{4}{*}{$\begin{array}{c}\text { Smatrate li da ćete tijekom idućih godina moći obavljati vaš posao s } \\
\text { obzirom na trenutno zdravstveno stanje? }\end{array}$} & Prilično sam siguran/a & 52 \\
\hline & Nisam siguran/a & 34 \\
\hline & To je nemoguće & 0 \\
\hline & Bez odgovora & 7 \\
\hline \multirow{5}{*}{ Jeste li u posljednje vrijeme aktivni i u pokretu? } & U većini slučajeva da & 21 \\
\hline & Prilično često & 46 \\
\hline & Ponekad & 20 \\
\hline & Prilično rijetko & 6 \\
\hline & Nikada & 0 \\
\hline \multirow{5}{*}{$\begin{array}{l}\text { Jeste li u posljednje vrijeme imali povjerenja u ono što se odnosi na } \\
\text { budućnost? }\end{array}$} & U većini slučajeva da & 9 \\
\hline & Prilično često & 32 \\
\hline & Ponekad & 31 \\
\hline & Prilično rijetko & 20 \\
\hline & Nikada & 1 \\
\hline \multirow{5}{*}{ Jeste li u posljednje vrijeme svoje dnevne zadaće izvršavali s veseljem? } & U većini slučajeva da & 20 \\
\hline & Prilično često & 34 \\
\hline & Ponekad & 35 \\
\hline & Prilično rijetko & 4 \\
\hline & Nikada & 0 \\
\hline
\end{tabular}


Tablica 7. Spearmanov koeficijent korelacije Rho (P vrijednost) WAI indeksa

Table 7. Spearman's correlation coefficient Rho (P value) of WAI index

\begin{tabular}{|c|c|c|c|}
\hline & \multicolumn{3}{|c|}{ Spearmanov koeficijent korelacije Rho (P vrijednost) WAI indeksa } \\
\hline & SB & $\mathbf{K}$ & Svi ispitanici \\
\hline \multicolumn{4}{|l|}{ Izazov, napredovanje i uključenost u rad organizacije } \\
\hline $\begin{array}{l}\text { Zadovoljni sa sadašnjom situacijom na poslu i } \\
\text { zanimanjem }\end{array}$ & $-0,088(0,60)$ & $-0,436(0,001)$ & $-0,296(0,004)$ \\
\hline Doživljavate li svoj poslovni život pretežno? & $0,003(0,98)$ & $-0,275(0,04)$ & $-0,139(0,18)$ \\
\hline $\begin{array}{l}\text { Dobivate li i Vi napredovanja tijekom razvoja } \\
\text { Vaše radne organizacije? }\end{array}$ & $-0,062(0,72)$ & $-0,064(0,65)$ & $-0,075(0,48)$ \\
\hline Doživljavate li da u Vašem zanimanju prevladava? & $-0,162(0,34)$ & $-0,183(0,19)$ & $-0,155(0,14)$ \\
\hline \multicolumn{4}{|l|}{ Kvaliteta života i uravnoteženost } \\
\hline $\begin{array}{l}\text { Koliko ste zadovoljni s trenutnom kvalitetom } \\
\text { Vašeg života? }\end{array}$ & $-0,441(0,006)$ & $-0,482(<0,001)$ & $-0,442(<0,001)$ \\
\hline Želite li ponekad prekinuti s Vašim poslom? & $-0,253(0,13)$ & $-0,413(0,002)$ & $-0,273(0,008)$ \\
\hline $\begin{array}{l}\text { Koja od navedenih rečenica najbolje opisuje Vašu } \\
\text { sadašnju životnu situaciju? }\end{array}$ & $-0,158(0,34)$ & $-0,286(0,04)$ & $-0,243(0,02)$ \\
\hline \multicolumn{4}{|l|}{ Sadašnja radna sposobnost } \\
\hline $\begin{array}{l}\text { Koliko ste trenutno uspješni u svladavanju fizičkih } \\
\text { zahtjeva na poslu? }\end{array}$ & $-0,685(<0,001)$ & $-0,350(0,009)$ & $-0,528(<0,001)$ \\
\hline $\begin{array}{l}\text { Koliko ste trenutno uspješni u svladavanju psihičkih } \\
\text { zahtjeva na poslu? }\end{array}$ & $-0,395(0,01)$ & $-0,449(0,001)$ & $-0,445(<0,001)$ \\
\hline $\begin{array}{l}\text { Koliko ste trenutno uspješni u svladavanju } \\
\text { međuljudskih zahtjeva na poslu? }\end{array}$ & $-0,238(0,16)$ & $-0,526(<0,001)$ & $-0,413(<0,001)$ \\
\hline Kako biste ocijenili zahtjeve vašeg radnog mjesta? & $-0,071(0,67)$ & $-0,132(0,34)$ & $-0,073(0,49)$ \\
\hline $\begin{array}{l}\text { Kada bi vašu najbolju radnu sposobnost ocijenili sa } \\
\text { 10, s koliko biste bodova ocijenili svoju sadašnju } \\
\text { radnu sposobnost? }\end{array}$ & $0,646(<0,001)$ & $0,536(<0,001)$ & $0,582(<0,001)$ \\
\hline $\begin{array}{l}\text { Osjećate li da ste u posljednje vrijeme pod stresom } \\
\text { (nemir, napetost, zabrinutost, nesanica kad pomisli na } \\
\text { neki problem)? }\end{array}$ & $-0,319(0,05)$ & $-0,601(<0,001)$ & $-0,452(<0,001)$ \\
\hline \multicolumn{4}{|l|}{ Zdravlje i blagostanje } \\
\hline Koliko se zdravo osjećate sveukupno gledano? & $-0,727(<0,001)$ & $-0,595(<0,001)$ & $-0,667(<0,001)$ \\
\hline Jeste li u posljednje vrijeme aktivni i u pokretu? & $-0,330(0,04)$ & $-0,365(0,006)$ & $-0,387(<0,001)$ \\
\hline $\begin{array}{l}\text { Jeste li u posljednje vrijeme imali povjerenja u ono što } \\
\text { se odnosi na budućnost? }\end{array}$ & $-0,187(0,26)$ & $-0,526(<0,001)$ & $-0,392(<0,001)$ \\
\hline $\begin{array}{l}\text { Jeste li u posljednje vrijeme svoje dnevne zadaće } \\
\text { izvršavali s veseljem? }\end{array}$ & $-0,343(0,04)$ & $-0,620(<0,001)$ & $-0,509(<0,001)$ \\
\hline \multicolumn{4}{|l|}{ Zdravstvena opterećenja } \\
\hline $\begin{array}{l}\text { Osjećate li u posljednje vrijeme da ste na radnom } \\
\text { mjestu izloženi zdravstvenim opterećenjima? }\end{array}$ & $-0,548(<0,001)$ & $-0,449(0,001)$ & $-0,442(<0,001)$ \\
\hline $\begin{array}{l}\text { Sprječava li vas u posljednje vrijeme u obavljanju } \\
\text { posla neka bolest ili ozljeda? }\end{array}$ & $-0,740(<0,001)$ & $-0,668(<0,001)$ & $-0,727(<0,001)$ \\
\hline $\begin{array}{l}\text { Koliko ste cijelih dana u posljednjih } 12 \text { mjeseci izostali } \\
\text { s posla zbog zdravstvenih problema? }\end{array}$ & $-0,249(0,13)$ & $-0,566(<0,001)$ & $-0,409(<0,001)$ \\
\hline $\begin{array}{l}\text { Smatrate li da ćete tijekom idućih godina moći } \\
\text { obavljati vaš posao s obzirom na trenutno zdravstveno } \\
\text { stanje? }\end{array}$ & $-0,713(<0,001)$ & $-0,618(<0,001)$ & $-0,600(<0,001)$ \\
\hline Broj bolesti dijagnosticiranih od liječnika & $-0,691(<0,001)$ & $-0,588(<0,001)$ & $-0,637(<0,001)$ \\
\hline
\end{tabular}


Uočena je povezanost niže vrijednosti WAI indeksa s onima koji su u procjeni:

- Izazova, napredovanja i uključenosti u rad organizacije

- nezadovoljniji sa sadašnjom situacijom na poslu i zanimanjem $($ Rho $=-0,296 \mathrm{P}=$ $0,004)$

- Kvalitete života i uravnoteženosti

- trenutno nezadovoljniji svojom kvalitetom Života $($ Rho $=-0,442 \mathrm{P}<0,001)$

- žele prekinuti s poslom (Rho $=-0,273$ $\mathrm{P}=0,008$ )

- trenutno nezadovoljniji profesionalnim ili privatnim životom $(\mathrm{Rho}=-0,243 \mathrm{P}=0,02)$

- Sadašnje radne sposobnosti

- trenutno lošiji u svladavanju fizičkih zahtjeva na poslu (Rho $=-0,528 \mathrm{P}<0,001)$

- trenutno lošiji u svladavanju psihičkih zahtjeva na poslu ( $R$ ho $=-0,445 \mathrm{P}<0,001$ )

- trenutno lošiji u svladavanju međuljudskih zahtjeva na poslu (Rho $=-0,413 \mathrm{P}<0,001)$

- niže ocijenili svoju sadašnju radnu sposobnost $(\mathrm{Rho}=0,582 \mathrm{P}<0,001)$

- $\mathrm{u}$ posljednje vrijeme pod stresom (Rho = $-0,452 \mathrm{P}<0,001)$
- Zdravlja i blagostanja

- osjećaju nezdravo (Rho = -0,667 P<0,001)

- slabije aktivni i u pokretu (Rho $=-0,387$ $\mathrm{P}<0,001)$

- imali manje povjerenja u ono što donosi budućnost (Rho $=-0,392 \mathrm{P}<0,001$ )

- rjeđe svoje zadaće izvršavali s veseljem $($ Rho $=-0,509 \mathrm{P}<0,001)$

- Zdravstvenih opterećenja

- u posljednje vrijeme na radnom mjestu izloženi većim zdravstvenim opterećenjima $($ Rho $=-0,442 \mathrm{P}<0,001)$

- prisiljeni u posljednje vrijeme u obavljanju posla raditi sporije ili promijeniti metodu rada $(\mathrm{Rho}=-0,727 \mathrm{P}<0,001)$

- s posla zbog zdravstvenih problema izostali više dana $($ Rho $=-0,409 \mathrm{P}<0,001)$

- nisu sigurni hoće li tijekom idućih godina moći obavljati svoj posao (Rho $=-0,600$ $\mathrm{P}<0,001)$

- imaju više bolesti dijagnosticiranih od strane liječnika (Rho $=-0,637 \quad \mathrm{P}<0,001)$.

Spearmanovim koeficijentom korelacije ocijenjeno je da nema značajne povezanosti WAI s godinama (Spearmanov koeficijent korelacije Rho $=$ $-0,139, \mathrm{P}=0,19,95 \% \mathrm{Cl}(-0,33$ do 0,07)); (Tablica 8).

Tablica 8. Povezanost WAI s godinama ispitanika

Table 8. Correlation between WAI and participants' age

\begin{tabular}{||l|c|c|c|c|}
\hline & Broj ispitanika & $\begin{array}{c}\text { Medijan (interkvartilni } \\
\text { raspon) dobi }\end{array}$ & minimum - maksimum & P* \\
\hline $\begin{array}{l}\text { Ponovno uspostaviti radnu } \\
\text { sposobnost }\end{array}$ & 4 & $26(24-27)$ & $23-27$ \\
\hline Poboljšati radnu sposobnost & 32 & $33(32-35)$ & $28-36$ \\
\hline Unaprijediti radnu sposobnost & 39 & $40(40-41)$ & $37-43$ \\
\hline Održati radnu sposobnost & 18 & $46(44-47)$ & $44-47$ \\
\hline
\end{tabular}

*Kruskal-Wallis test (post hocConover) 


\section{Zdravlje i blagostanje}

lako nisu statistički značajne ( $p>0,05)$,

razlike u samoprocjeni zdravlja i blagostanja među ispitanicima postoje.

\section{Tablica 9. Zdravlje i blagostanje}

Table 9. Health and well-being

\begin{tabular}{|c|c|c|c|c|}
\hline \multirow{2}{*}{ Zdravlje i blagostanje } & \multicolumn{3}{|c|}{ Broj $(\%)$ ispitanika } & \multirow[t]{2}{*}{$\mathbf{P}^{*}$} \\
\hline & SB & $\mathbf{K}$ & Ukupno & \\
\hline \multicolumn{5}{|c|}{ Koliko se zdravo osjećate sveukupno gledano? } \\
\hline 1. Vrlo zdravo & $2(5)$ & $11(20)$ & $13(14)$ & \multirow{4}{*}{0,06} \\
\hline 2. Prilično zdravo & $14(37)$ & $26(47)$ & $40(43)$ & \\
\hline 3. Osrednje zdravo & $18(47)$ & $14(25)$ & $32(34)$ & \\
\hline 4. Prilično nezdravo & $4(10)$ & $4(7)$ & $8(8)$ & \\
\hline \multicolumn{5}{|c|}{ Jeste li posljednje vrijeme aktivni i u pokretu? } \\
\hline 1. U većini slučajeva da & $4(11)$ & $17(31)$ & $21(23)$ & \multirow{4}{*}{0,14} \\
\hline 2. Prilično često & $22(58)$ & $24(44)$ & $46(49)$ & \\
\hline 3. Ponekad & $9(24)$ & $11(20)$ & $20(22)$ & \\
\hline 4. Prilično rijetko & $3(7)$ & $3(5)$ & $6(6)$ & \\
\hline \multicolumn{5}{|c|}{ Jeste li u posljednje vrijeme imali povjerenja u ono što se odnosi na budućnost? } \\
\hline 1. U većini slučajeva da & $2(5)$ & $7(13)$ & $9(10)$ & \multirow{5}{*}{0,19} \\
\hline 2. Prilično često & $14(37)$ & $18(33)$ & $32(34)$ & \\
\hline 3. Ponekad & $10(26)$ & $21(38)$ & $31(33)$ & \\
\hline 4. Prilično rijetko & $12(31)$ & $8(14)$ & $20(21)$ & \\
\hline 5. Nikada & 0 & $1(1,8)$ & $1(1,1)$ & \\
\hline \multicolumn{5}{|c|}{ Jeste li u posljednje vrijeme svoje dnevne zadaće izvršavali s veseljem? } \\
\hline 1. U većini slučajeva da & $5(13)$ & $15(27)$ & $20(22)$ & \multirow{4}{*}{0,21} \\
\hline 2. Prilično često & $18(47)$ & $16(29)$ & $34(37)$ & \\
\hline 3. Ponekad & $14(37)$ & $21(38)$ & $35(38)$ & \\
\hline 4. Prilično rijetko & $1(2)$ & $3(5)$ & $4(4)$ & \\
\hline
\end{tabular}

${ }^{*} \chi^{2}$ test 


\section{Zdravstvena opterećenja}

Statistički značajna razlika kod zdravstvenih opterećenja uočena je samo kod odgovora na pita- nje: Sprječava li Vas u posljednje vrijeme u obavljanju posla neka bolest ili ozljeda? Što od navedenog najbolje opisuje Vaše stanje? (Tablica 10).

\section{Tablica 10. Zdravstvena opterećenja}

\section{Table 10. Health threats}

\begin{tabular}{|c|c|c|c|c|}
\hline \multirow{2}{*}{ Zdravstvena opterećenja } & \multicolumn{3}{|c|}{ Broj (\%) ispitanika } & \multirow{2}{*}{$\mathbf{P}^{*}$} \\
\hline & SB & $\mathbf{K}$ & Ukupno & \\
\hline \multicolumn{5}{|c|}{ Osjećate li u posljednje vrijeme da ste na radnom mjestu izloženi zdravstvenim opterećenjima? } \\
\hline 1. Nimalo & $4(11)$ & $4(7)$ & $8(9)$ & \multirow{5}{*}{0,19} \\
\hline 2. Neznatno & $10(26)$ & $15(27)$ & $25(27)$ & \\
\hline 3. Osrednje & $19(50)$ & $18(33)$ & $37(40)$ & \\
\hline 4. Prilično jako & $5(13)$ & $15(27)$ & $20(21)$ & \\
\hline 5. Vrlo jako & 0 & $3(5)$ & $3(3)$ & \\
\hline \multicolumn{5}{|c|}{ Sprječava li Vas u posljednje vrijeme u obavljanju posla neka bolest ili ozljeda? Što od navedenog najbolje opisuje Vaše stanje? } \\
\hline 1. Sada me ne ometaju ni bolest niti ozljeda & $15(39)$ & $26(47)$ & $41(44)$ & \multirow{4}{*}{0,02} \\
\hline $\begin{array}{l}\text { 2. Mogu izvršavati svoj posao, ali to uzrokuje } \\
\text { tegobe }\end{array}$ & $11(29)$ & $25(45)$ & $36(39)$ & \\
\hline $\begin{array}{l}\text { 3. Ponekad sam prisiljen/a raditi sporije ili } \\
\text { promijeniti metodu rada }\end{array}$ & $10(26)$ & $3(5)$ & $13(14)$ & \\
\hline $\begin{array}{l}\text { 4. Često sam prisiljen/a raditi sporije ili } \\
\text { promijeniti metodu rada }\end{array}$ & $2(5)$ & $1(2)$ & $3(3)$ & \\
\hline \multicolumn{5}{|c|}{ Koliko ste cijelih dana u posljednjih 12 mjeseci izostali s posla zbog zdravstvenih problema (bolest, zdravstvena zaštita)? } \\
\hline 1. Nijedan dan & $24(63)$ & $37(67)$ & $61(66)$ & \multirow{8}{*}{0,32} \\
\hline 2. 1-9 dana & $7(18)$ & $10(18)$ & $17(18)$ & \\
\hline 3. 10-18 dana & $2(5)$ & $5(9)$ & $7(8)$ & \\
\hline 4. 19-24 dana & $1(2)$ & $2(3)$ & $3(3)$ & \\
\hline 5. 25-40 dana & 0 & $1(2)$ & $1(1)$ & \\
\hline 6. 41-60 dana & $3(7)$ & 0 & $3(3)$ & \\
\hline 7. 61-99 dana & 0 & 0 & 0 & \\
\hline 8. 100-365 dana & $1(2)$ & 0 & $1(1)$ & \\
\hline \multicolumn{5}{|c|}{ Smatrate li da ćete tijekom idućih godina moći obavljati Vaš posao (s obzirom na Vaše trenutno zdravstveno stanje)? } \\
\hline 1. Prilično sam siguran/a & $25(66)$ & $27(49)$ & $52(56)$ & \multirow{3}{*}{0,23} \\
\hline 2. Nisam siguran/a & $10(26)$ & $24(44)$ & $34(37)$ & \\
\hline Bez odgovora & $3(8)$ & $4(7)$ & $7(8)$ & \\
\hline \multicolumn{5}{|l|}{ Broj trenutnih bolesti dijagnosticiran od liječnika } \\
\hline 0 & $9(24)$ & $13(24)$ & $22(24)$ & \multirow{6}{*}{0,38} \\
\hline 1 & $6(16)$ & $8(15)$ & $14(15)$ & \\
\hline 2 & $2(5)$ & $9(16)$ & $11(12)$ & \\
\hline 3 & $4(10)$ & $10(18)$ & $14(15)$ & \\
\hline 4 & $5(13)$ & $5(9)$ & $10(10)$ & \\
\hline 5 & $12(31)$ & $10(18)$ & $22(2)$ & \\
\hline
\end{tabular}

${ }^{*} \chi^{2}$ test 


\section{RASPRAVA}

Između ispitivanih bolnica nema razlika $u$ ispitivanoj skupini čimbenika koji se odnose na izazov, napredovanja i uključenost u rad organizacije $(p>0,05)$. Spearmanov koeficijent korelacije (Rho)WAI i izazova, napredovanja i uključenosti u rad organizacije (svih ispitanika) ukazuje na snažnu povezanost niže vrijednosti WAI s onima koji su nezadovoljniji sa sadašnjom situacijom na poslu i zanimanjem $(\mathrm{Rho}=-0,296 \mathrm{P}=0,004)$.

Sadašnjom situacijom na poslu i zanimanjem natpolovična većina je nezadovoljna. Značajan podatak za upravu ustanova, jer istina je da ne treba zanemariti čimbenike na razini pojedinca. Potrebno je raščlaniti moguće organizacijske čimbenike. Ne ohrabruje podatak da se natpolovična većina ispitanika ne razvija usporedo s tijekom razvoja njihovih ustanova, rijetko ili nikad ne dobivaju u tim razdobljima napredovanja. Nasuprot tome, značajan je udio onih koji rade izravno surađujući, zajedno s kolegama, a također ohrabruje činjenica da je nemali udio onih koji svoj posao doživljavaju izazovnim, zanimljivim i smislenim i na tome treba graditi interventne mjere.

Rezultati su pokazali da kvalitetu svojeg života i uravnoteženost privatnog i radnog dijela, obje skupine ispitanika doživljavaju podjednako: pretežno su zadovoljni. Zamjetno je veliki broj nezadovoljnih trenutnom kvalitetom života, a najveći broj razmišlja o prekidu svojeg posla i čak želi prekinuti sa svojim poslom, te ne smatra svoj poslovni život ispunjenim. Svoju sadašnju životnu situaciju najvećim dijelom opisuju kao „ispunjen privatni život, a profesionalni ponekad".

Spearmanov koeficijent korelacije (Rho)WAI i kvalitete života ukazuje na snažnu povezanost niže vrijednosti WAI indeksa s onima koji su trenutno nezadovoljniji svojom kvalitetom života (Rho $=-0,442 \mathrm{P}<0,001)$, žele prekinuti s poslom (Rho $=-0,273 \mathrm{P}=0,008$ ), te su trenutno nezadovoljniji profesionalnim ili privatnim životom (Rho $=-0,243 \mathrm{P}=0,02)$.

Unutrašnji stresori su oni koji prvenstveno ovise o pojedincu, osobinama ličnosti, prethodnom iskustvu, stilu rada, sustavu vrijednosti, slici koju imaju o sebi, a očituju se kao nerealna očekivanja od posla i od sebe samog koja nadilaze radni realitet. Zbog toga se interventne mjere koje se odnose na cijelu ustanovu trebaju temeljiti na prepoznatim vanjskim stresorima, onima koji su povezani s radnim uvjetima, organizacijom rada $i$ onima koji izviru iz odnosa s drugim ljudima (Milošević, 2010.).

Prirodu posla i svoju sadašnju radnu sposobnost $\mathrm{u}$ pojedinim čimbenicima ispitanici u bolnicama procjenjuju značajno različito $(p<0,05)$. Razlika je značajna u tome koliko su uspješni u svladavanju fizičkih zahtjeva svojeg posla.

Značajne su razlike u zahtjevima radnog mjesta $(p<0,043)$. U zahtjevima radnog mjesta: očekivano su najvećim udjelom u obje ustanove ti zahtjevi miješani (fizički i psihički), međutim, psihički zahtjevi javljaju se dvostruko češće u zaposlenih u SB.

U samoprocjeni sadašnje radne sposobnosti ispitanici se također značano razlikuju $(p<0,036)$. Na skali od 1 do 10, gdje 1 predstavlja najlošiju, a 10 najbolju radnu sposobnost, na prva tri mjesta u SB najveći udio je procijenio svoju sadašnju radnu sposobnost sa 7 , zatim sa 8 , te sa 9 . U Klinici je najveći udio svoju sadašnju radnu sposobnost procijenio najboljom mogućom, 10, zatim sa 9, te sa 8. Osjećaj stresa u zadnje vrijeme ne navode sa značajnim razlikama.

Spearmanov koeficijent korelacije (Rho)WAI i sadašnje radne sposobnosti ukazuje na snažnu povezanost niže vrijednosti WAI s onima koji su trenutno lošiji u svladavanju fizičkih zahtjeva na poslu (Rho $=-0,528 \mathrm{P}<0,001)$, psihičkih zahtjeva na poslu (Rho $=-0,445 \mathrm{P}<0,001)$, međuljudskih zahtjeva na poslu (Rho $=-0,413 \mathrm{P}<0,001$ ), koji su niže ocijenili svoju sadašnju radnu sposobnost (Rho $=0,582 \mathrm{P}<0,001)$, te onima koji su u posljednje vrijeme pod stresom (Rho $=-0,452 \mathrm{P}<0,001)$.

lako nisu statistički značajne ( $p>0,05)$, razlike u samoprocjeni zdravlja i blagostanja među ispitanicima postoje. Iz te činjenice proizlazi i način života: aktivni način života, život u pokretu prilično često upražnjavaju obje skupine ispitanika.

Spearmanov koeficijent korelacije (Rho)WAI i samoprocjene zdravlja i blagostanja ukazuje na snažnu povezanost niže vrijednosti WAI s onima koji se osjećaju nezdravo (Rho $=-0,667 \mathrm{P}<0,001)$, koji su slabije aktivni i u pokretu (Rho $=-0,387$ 
$\mathrm{P}<0,001)$, koji imaju manje povjerenja $\mathrm{u}$ ono što donosi budućnost $($ Rho $=-0,392 \mathrm{P}<0,001)$ i rjeđe svoje zadaće izvršavaju s veseljem (Rho $=-0,509$ $\mathrm{P}<0,001)$.

Brojna su istraživanja odnosa uvjeta rada i ishoda za zdravlje i radnu sposobnost provedena u populaciji medicinskih sestara. Pojedina istraživanja pokazala su povezanost stresa na radu s emocionalnom iscrpljenošću (Hunter, 2004. Stordeur et al., 2001.), s fizičkom iscrpljenošću (Winwood et al., 2006.), bolovima u donjem dijelu leđa (Elfering et al., 2002.).

Visoki zahtjevi, te niska razina odlučivanja mogu biti povezani s povećanim rizikom za pojavu koronarne bolesti (Bosma et al., 1997.) i mentalnih poremećaja (Stansfeld, Candy, 2006.).

Najčešći uzroci stresa kod, na primjer, kineskih medicinskih sestara su neravnoteža između uloženog i dobivenog, loša slika sestrinstva u društvu i organizacijski problemi (Zeng, 2009.).

Adib- Hajbagheri izvijestio je da čimbenici poput organizacijske kulture, nedostatak podrške, nedostatak vremena rade pritisak na medicinske sestre i sprečava ih da poduzmu odgovarajuće kliničke odluke utemeljene na dokazima (Adib- Hajbagheri et al., 2003., Adib-Hajbagheri, 2007.).

Presječna studija provedena na čileanskim medicinskim sestrama zaposlenim u bolnicama pokazala je lošu kvalitetu života u domeni fizičkog zdravlja, ocijenjena instrumentom WHOQOL- BREF (Andrades Barrientos, Valenzuela Suazo, 2007.). Također, istraživanja su pokazala da je povećan broj medicinskih sestara koje napuštaju svoj posao u zemljama u tranziciji (Hasselhorn et al., 2004.).

Analiza povezanosti domena kvalitete života i radne sposobnosti u disertaciji R. Golubić (2010.) pokazala je da su fizičko i psihičko zdravlje značajni prediktori dobre radne sposobnosti. Zdravstveni djelatnici boljeg fizičkog zdravlja imaju 6,80 puta veće šanse za dobru radnu sposobnost nego oni lošeg fizičkog zdravlja. Također, zdravstveni djelatnici s boljim psihičkim zdravljem imaju 1,80 puta veće šanse za dobru radnu sposobnost nego oni lošeg psihičkog zdravlja. Od ostalih prediktora dobre radne sposobnosti u multivarijatnoj analizi, statistički značajni bili su dob i edukacijski stupanj (Golubić, 2010.).

U zdravstvenim opterećenjima među ispitanicima u ovom istraživanju nema statistički značajnih razlika $(p>0,05)$.

Spearmanov koeficijent korelacije (Rho) WAI i zdravstvenih opterećenja ukazuje na snažnu povezanost niže vrijednosti WAI s onima koji su u posljednje vrijeme na radnom mjestu izloženi većim zdravstvenim opterećenjima (Rho $=-0,442$ $\mathrm{P}<0,001$ ), prisiljeni u posljednje vrijeme u obavljanju posla raditi sporije ili promijeniti metodu rada (Rho $=-0,727 \mathrm{P}<0,001)$, koji su s posla zbog zdravstvenih problema izostali više dana (Rho $=-0,409$ $\mathrm{P}<0,001)$, koji nisu sigurni hoće li tijekom idućih godina moći obavljati svoj posao (Rho $=-0,600$ $\mathrm{P}<0,001)$ i koji imaju više bolesti dijagnosticiranih od strane liječnika (Rho = -0,637 $P<0,001)$.

Ispitanici uglavnom ne izostaju s posla zbog zdravstvenih problema, a ako i izostanu onda su to kratki izostanci u trajanju od 1 do 9 dana. Svega je jedan ispitanik u obje skupine izostao 25-40 dana.

Na pitanje smatraju li da će tijekom idućih godina moći obavljati svoj posao s obzirom na trenutno zdravstveno stanje, u SB četvrtina ispitanika nije sigurna. Dosadašnja istraživanja pokazuju da odgovor na ovo pitanje ima najveću korelaciju s objektivnom radnom sposobnošću (Karasek et al., 1981.).

Spearmanovim koeficijentom korelacije ocijenjeno je da nema značajne povezanosti WAI s godinama (Spearmanov koeficijent korelacije Rho $=-0,139, \mathrm{P}=0,19,95 \% \mathrm{Cl}(-0,33$ do 0,07$)$.

\section{Prijedlog preventivnih mjera}

Razumijevanje radnog stresa i njegova utjecaja na zaposlenike važni su za cijelu ustanovu zbog pravovremenog otklanjanja neželjenih posljedica, a upravljanje stresom jedna je od temeljnih vještina zdravog življenja. Stoga je potrebno na razini pojedinca izgraditi svijest kako će životni zahtjevi, okolnosti i događaji djelovati na samu osobu i kakve će biti njezine reakcije, te kakvi će ih odgovori organizma pratiti. 
Sve stresore prisutne na određenom radnom mjestu, odnosno u određenom načinu rada nije moguće ukloniti, ali može se pomoći utječući na vanjske okolnosti ili individualnu osjetljivost da se simptomi stresa umanje (McCunney, 2002.).

Medicinskim sestrama/tehničarima koristile bi vještine suočavanja sa stresom usmjerene na pokušaj promjene onog što mogu promijeniti:

1. svoju percepciju i stav u odnosu na problem tako da povećaju vlastitu svijest o svojim sposobnostima za rješavanje neke situacije i granicama tolerancije na stres

2. odnos prema okolini na način da prilagode ciljeve, organizaciju vremena i odnos prema obvezama tako da bi ih mogle ispuniti

3. poboljšanje vlastite tjelesne spremnosti redovitom i odgovarajućom prehranom, smanjenjem unosa šećera, kofeina i nikotina, te redovitim tjelesnim vježbanjem.

Kontrola stresa na poslu moguća je u obliku:

1. Samozaštite - uključuje prepoznavanje simptoma izgaranja na poslu, utvrđivanje strategije samozaštite i određivanje konkretnih načina i tehnika samozaštite.

2. Suzaštite - uključuje organizaciju posla i socijalnu podršku.

3. Profesionalne pomoći - stručna pomoć uključuje savjetovanje, superviziju, konzultacije i zajedničko rješavanje problema.

Očuvanje radne sposobnosti od velike je važnosti kako za medicinske sestre/tehničare, tako i za širu društvenu zajednicu zbog značaja i osjetIjivosti posla koje obavljaju. U novije vrijeme se procjena učinkovitosti intervencijskih mjera unapređenja uvjeta i načina rada u svrhu očuvanja zdravlja zaposlenih sve češće stavlja u kontekst kvalitete života (Golubić, 2010.).

U domeni kvalitete života rezultati ukazuju na potrebu intervencije u smislu radne okoline i organizacije rada koje se odnose na prevenciju i svladavanje stresa na radnom mjestu (Marine et al., 2006., Mimura, Griffiths, 2003.), redovite sastanke s kolegama i šefovima, redistribuciju smjenskog rada (Barnes-Farrell et al., 2008.), te kontinuirano unapređenje pravilnika u vezi sa štetnostima i opasnostima na radnom mjestu.
Radna organizacija ima središnju ulogu u održavanju radne sposobnosti svojih djelatnika i promociji zdravlja na radnom mjestu. Održavanje radne sposobnosti i promocija zdravlja na radnom mjestu zahtijeva dobru suradnju između zaposlenika i nadređenih, pri čemu dolazi do podjele odgovornosti. Intervencije bi trebale biti usmjerene na karakteristike posla i njegovu organizaciju (Golubić, 2010.).

\section{ZAKLJUČCI}

Na temelju istraživanja najizrazitijih stresora u svakodnevnom radu medicinskih sestara/ tehničara dvije bolnice te kako djeluju na njihovo zdravlje, radnu sposobnost i kvalitetu života može se zaključiti sljedeće:

- lako se radi o relativno malom uzorku ispitanika ( $\mathrm{N}=38$, odnosno $\mathrm{N}=55$ ), dobivene rezultate treba promatrati kao pokazatelje izvora organizacijskih čimbenika stresa i kao takvih uporišta na kojima se mogu planirati interventne mjere;

- Natpolovična većina ispitanika o čimbenicima koji se odnose na izazov, napredovanje i uključenost u rad organizacije je nezadovoljna (52\%, odnosno $63 \%$ ), petina ispitanika posao smatra obvezom i sve više odbojnim, te preko $60 \%$ nema mogućnost napredovanja;

- Između ispitivanih bolnica nema razlika u skupini čimbenika koji se odnose na izazov, napredovanja i uključenost u rad organizacije ( $p>0,05)$;

- Zamjetno je veliki broj nezadovoljnih trenutnom kvalitetom života, a najveći broj zaposlenika razmišlja o prekidu svojeg posla pa čak i želi prekinuti sa svojim poslom, te ne smatraju svoj poslovni život ispunjenim;

- Sadašnja radna sposobnost prikazana je indeksom radne sposobnosti. Od 93 ispitanika:

- WAI 7 - 27 imaju 4 ispitanika (pokazuje lošu radnu sposobnost)

- WAI 28 - 36 ima 32 ispitanika (pokazuje dobru radnu sposobnost) 
- WAI 37 - 43 ima 39 ispitanika (pokazuje vrlo dobru radnu sposobnost) i

- WAI 44 - 49 ima 18 ispitanika (pokazuje odličnu radnu sposobnost).

Spearmanov koeficijent korelacije (Rho) WAI i:

- kvalitete života ukazuje na snažnu povezanost niže vrijednosti WAI indeksa s onima koji su trenutno nezadovoljniji svojom kvalitetom života, žele prekinuti s poslom, te su trenutno nezadovoljniji profesionalnim ili privatnim životom

- sadašnje radne sposobnosti ukazuje na snažnu povezanost niže vrijednosti WAI s onima koji su trenutno lošiji u svladavanju i fizičkih i psihičkih, kao i međuljudskih zahtjeva na poslu, koji su niže ocijenili svoju sadašnju radnu sposobnost, te onima koji su u posljednje vrijeme pod stresom

- samoprocjene zdravlja i blagostanja ukazuje na snažnu povezanost niže vrijednosti WAI s onima koji se osjećaju nezdravo, koji su slabije aktivni i u pokretu, koji imaju manje povjerenja u ono što donosi budućnost i rjeđe svoje zadaće izvršavaju $\mathrm{s}$ veseljem

- zdravstvenih opterećenja ukazuje na snažnu povezanost niže vrijednosti WAI s onima koji su u posljednje vrijeme na radnom mjestu izloženi većim zdravstvenim opterećenjima, prisiljeni u posljednje vrijeme u obavljanju posla raditi sporije ili promijeniti metodu rada, koji su s posla zbog zdravstvenih problema izostali više dana, koji nisu sigurni hoće li tijekom idućih godina moći obavljati svoj posao i koji imaju više bolesti dijagnosticiranih od strane liječnika.

Spearmanovim koeficijentom korelacije ocijenjeno je da nema značajne povezanosti WAI s godinama. Predložene su mjere poboljšanja u suočavanju sa stresom i mjere poboljšanja kvalitete života i radne sposobnosti.

$U$ interventnim mjerama svakako bi trebalo koristiti dragocjen podatak najbolje ocijenjenog čimbenika: suradnja s kolegama na poslu.

\section{LITERATURA}

Adib- Hajbagheri, M., Salsali, M., Ahmadi, F.: Clinical Decision- Making: A way to Professional empowerment in nursing. Iran J Med Educ, 2003., 3:3- 13 .

Adib- Hajbagheri, M.: Factors facilitating and inhibiting evidence- based nursingin Iran. $\int A d v$ Nurs, 2007., 58:566-75 (Pub Med).

Andrades Barrientos, L., Valenzuela Suazo, S.: Quality of life associated factors in Chileans Hospital nurses. Rev Lat Am Enfermagem., 2007., 15:480-6.

Barnes-Farrell, JL. et al.: What aspects of shift work in fluence off-shiftwell-being of health care workers? App/ Ergon, 2008., 39:589-96.

Blore, J.: Subjective Wellbeing: An Assessment of Competing Theories. Deakin University, Greelong, Australija, 2008.

Bosma, $\mathrm{H}$. et al.: Low job control and risk of coronary disease in Whitehall II (prospective cohort) study. BMJ, 314 (7080), 1997., p. 558-65

Cummins, R. A., ed.: Comprehensive Quality of Life Scale for Adults (Com Qol- 4) 4th ed. Deakin University, School of Psychology. Melbourne,1993.

Cummins, R.A.: Objective and Subjective Quality of Life: An Interactive Model. Social Indicators Research, 2000: 55-72

Elfering, A. et al.: Time control, catecholamines and back pain among young nurses. Scand J Work Environ Health, 28, 2002., 6, p. 386-93.

Eurofound. European Foundation for the Improvement of Living and Working Conditions: European Working Conditions Surveys (EWCS). 2004-2009; Dostupno na: http://www.eurofound. europa.eu/working/surveys/. Pristupljeno: 10. 6. 2016.

Germano, D.: Quality of life and sense of Coherence in People with Arthritis. School of Psychology. Faculty of Health and Behavioural 
Science, Deakin University (Burwood); (Australija), 1996.

Golubić, R.: Domene kvalitete života kao prediktori radne sposobnosti bolničkih zdravstvenih djelatnika. Doktorska disertacija, Medicinski fakultet Sveučilišta u Zagrebu, Zagreb, 2010.

Hasselhorn, H.M., Tackenberg, P. and Peter, R.: Effort- reward in balance among nurses Instable countries and in countries in transition. Int J Occup Environ Health, 10, 2004., 4, p. 401-8.

Hunter, B.: Conflicting ideologies as a source of emotion work in midwifery. Midwifery, 20, 2004., 3, p. 261-72.

Karasek, R. A. et al.: Job decision latitude, job demands, and cardiovascular disease: a Prospective study of Swedishmen. Am J Public Health, 71, 1981., 7, 694-705.

Karasek, R.A. et al.: Job, psychological factors and coronary heart disease. Swedish Prospective findings and US prevalence findings using a new Occupational inference method. Adv Cardiol, 29, 1982., 62-7.

Karasek, R.A. et al.: Job, characteristics in relation to the prevalence of myocardial Infarction in the US Health Examination Survey (HES) and the Health and Nutrition Examination Survey (HANES). Am J Public Health, 78, 1988., 8, p. 910-8.

Kinzl, J.F. et al.: Burnout and stress disorders in intensive care doctors. Dtsch Med Wochenschr, 131, 2006., 44, p. 2461-4.

Leka, S., Griffiths, A. and Cox, T.: Work organization and stress: systematic problem approaches for employers, ed. World Health Organization, Geneva, 2003.

Marine, A., Ruotsalainen, J., Serra, C., Verbeek, J.: Preventing occupational stress in health care workers. Cochrane Database Syst Rev, 2006:CD002892.

McCunney, R. J.: Psychiatric Aspects of Occupational Medicine. A Practical Approach to Occupational and Enviromental Medicine, Little, Brown and Company, Boston,1994.

Milošević, M.: Izrada mjernog instrumenta stresa na radnom mjestu bolničkih zdravstvenih djelatnika i procjena njegove uporabne vrijednosti. Doktorska disertacija, Medicinski fakultet Sveučilišta u Zagrebu, Zagreb, 2010.

Mimura, C., Griffiths, P.: The effectiveness of current approaches to work place stressmanagement in the nursing profession: an evidence based literature review. Occup Environ Med, 60, 2003., 1, 10-5.

Paravlić, F.: Profesionalne i neprofesionalne bolesti medicinske sestre. U: 3. kongres Hrvatske udruge medicinskih sestara s međunarodnim sudjelovanjem. Knjiga radova, Zagreb, Hrvatska. 2006. (p. 239-243).

Pavičević, L. et al.: Stres na radu. U: Medicina rada i okoliša (Šarić, M. i Žuškin, E., ur.), Medicinska naklada, Zagreb, 2002.

Robinson, J.R., Clements, K., and Land, C.: Work place stress among psychiatric nurses. Prevalence, distribution, correlates, \& predictors. J Psychosoc Nurs Ment Health Serv, 41, 2003., 4, p. 32-41.

Stansfeld, S., Candy, B.: Psychosocial work environment and mentalhealth - a meta-Analytic review. Scand J Work Environ Health, 32, $2006 .$, 6, p. 443-62.

Stordeur, S., D'Hoore, W. and Vandenberghe, C.: Leadership, organizational stress, and emotional exhaustion among hospital nursing staff. J $A d v$ Nurs, 35, 2001., 4, p. 533-42.

Šarić, M., Žuškin, E.: Medicina rada i okoliša. Medicinska naklada, Zagreb, 2002.

Ventegodt, S.: Quality of Life Theory I. The IQOL Theory: An Integrative Theory of the Global Quality of Life Concept. The Scientific World Journal, 2003., 3, 1030-1040.

Visser, M.R. et al.: Stress, satisfaction and burn out among Dutch medical specialists. CMAJ, 168, 2003., 3, p. 271-5.

Zeng, Y.: Review of work-related stres in mainland Chinese nurses. Nurs Health Sci, 11, 2009., 1, p. 90-7.

Winwood, P.C., Winefield, A.H. and Lushington, K.: Work-related fatigue and recovery: the contribution of age, domestic responsibilities and shiftwork. J. Adv Nurs, 56, 2006., 4, p. 438-49. 


\section{MAINTAINING THE QUALITY OF PERSONAL LIFE, HEALTH AND WORK CAPACITY OF NURSES}

SUMMARY: The objective of the study was to identify the most prevalent stressors in the everyday workload of nurses and medical technicians that impact their health, work capacity and quality of life. Differences were found regarding the results obtained in two different hospitals explainable by the type of work that participants do in their daily routine activities. Measures are suggested to improve coping with stress and those that will contribute to a better quality of life, personal health and work capacity. The study was conducted on a sample of 93 nurses/technicians employed at a special hospital (SH), (N=38), and a clinic (C), $(\mathrm{N}=55)$. The participation in the study was voluntary and anonymous and used the Questionnaire for the Assessment of the Impact of Work on Health and Work Capacity. The obtained data was fed into a data base (Microsoft Excel the Windows) with a descriptive statistical analysis following. The differences in category variables were analysed using the chi-square test. $P$ values $<0.05$ were regarded as significant. The analysis relied on STATISTICA version 10.0 (www.statsoft. com) and WAI correlation was investigated with the responses from the Questionnaire using Spearman's correlation coefficient. The study was approved by the Ethics Committee at the Faculty of Medicine, University of Zagreb. No differences were found in the two facilities with respect to factors such as challenge, promotion and involvement in the work of the organisation ( $p>0.05$ ). More than a half (52\% and $63 \%$ respectively) was dissatisfied. Over one half of the subjects (55\% and 58\%) wished to sometimes stop with their work, and a fifth found work a mere obligation and increasingly repulsive. $62 \%$ complained of no chance for promotion. The best element of the work for most subjects was the collaboration with other colleagues. As for the quality of life, a great majority found it partly satisfying or unsatisfying (48\%). The lower WAI values were found to be in strong correlation to dissatisfaction with work, and with the quality of life, poorer performance at work, poorer health and health overload. Despite the relatively small study sample ( $N=38$ and $N=55)$, the results should be interpreted as indicators of the sources of stress that are directly related to the organisational factors and should serve as the base in planning improvement measures. Measures are proposed to cope better with stress, preserve the quality of life and work capacity. Intervention measures should take into account the precious factor of excellent collaboration with colleagues at work.

Key words: nurse/technician, personal health, quality of life, work capacity

Original scientific paper Received: 2018-07-04

Accepted: 2019-04-16 